\title{
Toxicity and residual effects of insecticides on Ascia monuste and predator Solenopsis saevissima
}

\author{
Tamíris A de Araújo, ${ }^{a^{*}}$ Marcelo C Picanço, ${ }^{b}$ Dalton de O Ferreira, \\ Júlia ND Campos, ${ }^{b}$ Lucas de P Arcanjo $^{b}$ and Gerson A Silva ${ }^{c}$
}

\begin{abstract}
BACKGROUND: Investigating the impact of pesticides on non-target organisms is essential for sustainable integrated pest management programs. We therefore assessed the toxicity of ten insecticides to the brassica caterpillar Ascia monuste and its ant predator Solenopsis saevissima and examined the effect that the insecticide synergists had on toxicity to the predator. We also assessed the residual period of control and impact of the insecticides during the brassica growing cycle.

RESULTS: All insecticides except flubendiamide exhibited mortality above the threshold required by Brazilian legislation (80\%). Chlorantraniliprole, cyantraniliprole, indoxacarb and spinosad exhibited lower toxicity to the ant predator than they did to the brassica caterpillar. The results obtained for synergized insecticides suggest that selectivity to the predator was due the involvement of cytochrome P450-dependent monooxygenases. Chlorfenapyr and cyantraniliprole exhibited the highest residual periods of control to the brassica caterpillar, whereas malathion had the greatest impact on the predator.

CONCLUSION: Most of the insecticides efficiently controlled the brassica caterpillar, but not all exhibited selectivity to the predator. Therefore, due to the distinctive responses of organisms with respect to residual periods of control and the impact of the insecticides, spraying frequency must be strongly considered in integrated pest management programs.

(c) 2017 Society of Chemical Industry
\end{abstract}

Keywords: fire ant; Pieridae; physiological selectivity; synergists; residual period of control

\section{INTRODUCTION}

In agricultural ecosystems, insecticides are the main mode of control of insect pests. ${ }^{1}$ The insecticides that are used in pest management programs must be effective in controlling pests and have a low impact on non-target organisms, such as natural enemies. Determining the residual period of control for an insecticide is essential to plan insect management strategies, which will influence the spraying frequency and, in turn, affect pest control costs. ${ }^{2}$ In addition to being efficient in controlling pests, each insecticide must possess a different mechanism of action to avoid the pressure of pest population selection for insecticide resistance. ${ }^{3}$

To study the effect of insecticides on natural enemies, it is important to understand the selectivity of these insecticides toward non-target organisms. The selectivity of insecticides toward natural enemies can be achieved in two ways: ecological selectivity and physiological selectivity. ${ }^{4}$ Ecological selectivity includes the application of insecticides in a manner that minimizes the exposure of natural enemies to the insecticides. This selectivity can be achieved by insecticide application in places or periods that minimize its contact with natural enemies, whereas physiological selectivity employs the use of insecticides that are more toxic to the pest than they are to natural enemies. ${ }^{5,6}$

The use of physiological selectivity on natural enemies requires knowledge about the detoxification process of insecticides in these organisms. Furthermore, to determine the detoxification process involved in physiological selectivity, synergists may be used. ${ }^{6}$ Synergists are compounds that inhibit the main groups of detoxifying enzymes in insects. For example, triphenyl phosphate is a synergistic inhibitor of esterases - enzymes that, in insects, are responsible for processes involved in the central nervous system, ${ }^{7}$ sensory neurons, ${ }^{8}$ reproductive behavior, ${ }^{9}$ juvenile hormone regulation ${ }^{10}$ and degradation of insecticides. ${ }^{11}$ Diethyl malate, in turn, is an inhibitor of glutathione S-transferase, which is a multifunctional enzyme that is involved in the detoxification of several xenobiotic compounds including insecticides. ${ }^{12}$ Piperonyl butoxide acts as an inhibitor of cytochrome P450-dependent monooxygenases - enzymes that not only metabolize insecticides but also promote their bioactivation. ${ }^{13,14}$

For cultivated plants, pests belonging to the order Lepidoptera are one of the primary groups of pests. Pieridae, an important

Correspondence to: TA de Araújo, Departamento de Fitotecnia, Universidade Federal de Viçosa, Av. PH Rolfs, s/n, 36570-900, Viçosa, MG, Brazil. E-mail: tamirisaa@gmail.com

a Departamento de Fitotecnia, Universidade Federal de Viçosa, Viçosa, MG, Brazil

b Departamento de Entomologia, Universidade Federal de Viçosa, Viçosa, MG, Brazil

c Centro de Ciências e Tecnologias Agropecuárias, Universidade Estadual do Norte Fluminense Darcy Ribeiro, Campos dos Goytacazes, RJ, Brazil 


\begin{tabular}{|c|c|c|c|c|c|c|}
\hline Insecticide & $\begin{array}{l}\text { Chemical subgroup } \\
\text { or exemplifying active }\end{array}$ & Manufacturer & $\begin{array}{c}\text { Rate } \\
\left.\text { (mg a.i. } \mathrm{mL}^{-1}\right)\end{array}$ & $\begin{array}{l}\text { Water solubility } \\
\qquad\left(\mathrm{mg} \mathrm{L}^{-1}\right)\end{array}$ & $\begin{array}{l}\text { Vapor pressure } \\
(\mathrm{mm} \mathrm{Hg})\end{array}$ & $\begin{array}{l}\text { Half-life on leaf } \\
\text { (days) }\end{array}$ \\
\hline Cartap 500 SP & Nereistoxin analogs & Iharabrás SA & 0.60 & 200000 & $7.7 \times 10^{-7}$ & 12 \\
\hline Cyantraniliprole 100 OD & Diamides & Du Pont do Brasil SA & 0.50 & 14.20 & $<3.85 \times 10^{-17}$ & 35 \\
\hline Chlorantraniliprole 100 SC & Diamides & Du Pont do Brasil SA & 0.015 & 1.00 & $1.2 \times 10^{-14}$ & 210 \\
\hline Chlorfenapyr 240 SC & Chlorfenapyr & BASF SA & 0.18 & 0.14 & $7.36 \times 10^{-8}$ & 3.5 \\
\hline Deltamethrin $25 \mathrm{EC}$ & Pyrethroids & Bayer SA & 0.0075 & 0.0002 & $1.5 \times 10^{-8}$ & 11 \\
\hline Spinosad $480 \mathrm{SC}$ & Spinosyns & Dow AgroSciences & 0.432 & 235 & $2.4 \times 10^{-10}$ & 9 \\
\hline Flubendiamide $480 \mathrm{SC}$ & Diamides & Bayer SA & 0.0336 & 0.03 & $<7.5 \times 10^{-7}$ & - \\
\hline Indoxacarb 300 WG & Indoxacarb & Du Pont do Brasil SA & 0.10 & 0.20 & $1.9 \times 10^{-10}$ & 18 \\
\hline Malathion $1000 \mathrm{EC}$ & Organophosphates & Cheminova SA & 1.50 & 125 & $3.97 \times 10^{-5}$ & 4.5 \\
\hline Methomyl 215 SL & Carbamates & Du Pont do Brasil SA & 0.215 & 54700 & $5.4 \times 10^{-6}$ & 1.1 \\
\hline
\end{tabular}

family in this group, includes pest species occurring in Africa, Europe, Asia and the Americas. ${ }^{15}$ Some species in this family, such as Ascia monuste (Godart), attack plants in the Brassicaceae family in South, Central and North America. ${ }^{16}$ A. monuste attacks cabbage, cauliflower, broccoli, Brussels sprout, kale and canola. ${ }^{17}$ The larvae of $A$. monuste defoliate the plants and may cause production losses of up to $100 \% .{ }^{18}$ Among the natural enemies of $A$. monuste is the ant predator Solenopsis saevissima (Smith) (Hymenoptera: Formicidae). ${ }^{19}$ These ants are predators of different species, mainly lepidopterans, and prey on pupae and larvae of all instars. ${ }^{20}$ The ants' nidification occurs in soil, and their foraging activity occurs at night because of the lower temperatures. ${ }^{19}$

Therefore, in this work, we aim to identify insecticides that can be used in integrated management programs of $A$. monuste. The following parameters were determined: (i) the insecticides' efficiency in controlling A. monuste; (ii) the physiological selectivity of insecticides to the predator S. saevissima; (iii) the toxicity of synergized insecticides to S. saevissima; (iv) the insecticides' residual period of control of A. monuste; and ( $v$ ) the insecticides' impact on the predator as a function of time after spraying in the greenhouse.

\section{MATERIAL AND METHODS}

\subsection{Plants}

Cabbage plants of Sacaia hybrid were cultivated in a greenhouse in $5 \mathrm{~L}$ plastic pots at the campus of the Universidade Federal de Viçosa (UFV), Viçosa, MG, Brazil ( $20^{\circ} 48^{\prime} 45^{\prime \prime} \mathrm{S}, 42^{\circ} 56^{\prime} 15^{\prime \prime} \mathrm{W} ; 600 \mathrm{~m}$ altitude; tropical climate). The plants were cultivated employing usual cultural practices without the use of pesticides. All bioassays were conducted in our laboratory, which was maintained at $25 \pm 1{ }^{\circ} \mathrm{C}$ with a relative humidity of $75 \pm 5 \%$ under a $12: 12 \mathrm{~h}$ photoperiod.

\subsection{Insects}

The larvae (second instar) of $A$. monuste and adults of the ant predator S. saevissima were used in the bioassays. The adults of the ant predator were collected from nests at the UFV campus, and $A$. monuste larvae were reared in a greenhouse at the same location. Greenhouse colonies were established from A. monuste larvae that were originally collected in commercial brassica crops in Viçosa county. As adults, A. monuste were fed a diluted honey solution in water ( $20 \%$ water). The oviposition of butterflies occurred in cabbage plants, and the larvae were fed cabbage leaves.

\subsection{Insecticides}

The insecticides' characteristics and recommended field rates for use in bioassays are described in Table 1. The selected insecticides belong to different chemical groups that are the most popular for controlling caterpillars, and some are the newest products available. ${ }^{21}$ To the insecticide solution was added $1 \mathrm{~mL} \mathrm{~L}^{-1}$ spreader-sticker nonylphenol polyethylene glycol ether 125 SC (Milenia Agro Ciências SA, Londrina, Brazil). In the bioassays to determine the toxicity of synergized insecticides towards the predator, water + spreader-sticker + synergist was used as the control. In other bioassays, water + spreader-sticker was used as the control.

\subsection{Selection of insecticides that effectively control A. monuste}

The selection bioassay was performed in a completely randomized design with six replicates for each treatment (insecticides at recommended field rates and the control) (Table 1). Each replicate consisted of one plastic pot $(250 \mathrm{~mL})$ with ten larvae (second instar) of $A$. monuste. First, cabbage leaf disks (diameter $7.5 \mathrm{~cm}$ ) were immersed for $5 \mathrm{~s}$ in each treatment solution. The disks were then allowed to dry in the shade for $2 \mathrm{~h}$, and the dried disks were subsequently placed in a plastic pot $(250 \mathrm{~mL})$. We assessed the mortality of $A$. monuste after $48 \mathrm{~h}$ of exposure. The insects were considered dead when they did not move when touched with a paintbrush. For the next bioassay, we chose the insecticides that caused $\geq 80 \%$ mortality of $A$. monuste. This mortality threshold was used because, in Brazil, an insecticide is considered efficient if it results in at least $80 \%$ mortality of the pest. $^{22}$

\subsection{Physiological selectivity of insecticides to S. saevissima}

The physiological selectivity bioassay was performed in a completely randomized design with six replicates for each treatment (insecticides at recommended field rates and the control). Each replicate consisted of one plastic pot $(250 \mathrm{~mL})$ containing ten adults of S. saevissima and a cabbage leaf disk (diameter $7.5 \mathrm{~cm}$ ) treated as described above. To feed the ants, honey solution (1:1) and pure water were provided in plastic containers $(1.5 \mathrm{~cm}$ diameter $\times 1.0 \mathrm{~cm}$ height) inside each pot. We assessed the mortality of S. saevissima after $48 \mathrm{~h}$ of exposure. 


\subsection{Insecticide synergist bioassay}

These treatments consisted of insecticides that showed physiological selectivity to the predator S. saevissima in the previous bioassay. The treatments included insecticides and the insecticide + synergist combination as well as the control. The bioassay was performed with the following synergists: piperonyl butoxide, diethyl maleate and triphenyl phosphate (all from Sigma-Aldrich Brasil Ltda, São Paulo, Brazil). The insecticides were applied to leaf disks as described in the previous bioassay. The foliar disks were immersed for $5 \mathrm{~s}$ in each treatment solution and allowed to dry in the shade for $2 \mathrm{~h}$. Then, the synergist solution (10\% synergist and $90 \%$ acetone) was applied to cabbage leaf disks containing dried insecticide residue by spraying the solution. The solution was sprayed at 1.03 bar pressure (Burkard ${ }^{\circledR}$, Potter spray tower - manual load, BS00282) with a synergist concentration of $1.5 \mathrm{mg} \mathrm{mL}^{-1}$. $^{23}$ This concentration of synergist, which did not cause the mortality of the predator, was determined in the previous bioassay. Then, one leaf disk and ten adults of S. saevissima were placed in the plastic pot $(250 \mathrm{~mL})$. We assessed the mortality to $S$. saevissima after $48 \mathrm{~h}$ of exposure.

\subsection{Residual period of control of $A$. monuste and impact of insecticides on the predator S. saevissima as a function of time after spraying in the greenhouse}

This bioassay was carried out at the UFV campus from November 2014 to January 2015. Cabbage plants were cultivated in $5 \mathrm{~L}$ plastic pots employing usual cultural practices. The insecticide treatments for $A$. monuste were cartap, chlorantraniliprole, chlorfenapyr, cyantraniliprole, deltamethrin, indoxacarb, malathion, methomyl and spinosad, as well as the control (water + spreader-sticker). The insecticide treatments for S. saevissima that did not show physiological selectivity to the predator were cartap, chlorfenapyr, deltamethrin, malathion and methomyl, and the control (water + spreader-sticker). In this bioassay, 50 cabbage plants were used, and the plants were 30 days old after transplanting (15 leaves per plant) at the beginning of the bioassay. The experimental design consisted of randomized blocks with five replications, and each replicate consisted of one plant. For insecticide application, a $\mathrm{CO}_{2}$-pressurized backpack sprayer, at 3.1 bar pressure, a flow rate of $240 \mathrm{~L} \mathrm{ha}^{-1}$, and using a tip-type MGA 8002 (Magnojet, Commercial Industry of Agricultural Products LTDA, Paraná-PR, Brazil), was used. The plants were sprayed according to the treatments (insecticides and control) and were then allowed to dry in the shade for $2 \mathrm{~h}$ and kept in a greenhouse. The new leaves that grew were not sprayed or used in the bioassays. During the experimental period inside the greenhouse, the temperature was $30.79 \pm 0.61^{\circ} \mathrm{C}$, with a relative humidity of $55.94 \pm 1.46 \%$, a photoperiod of $13: 11 \mathrm{~h}$ and insolation of $943.53 \mathrm{~kJ} \mathrm{~m}^{-2}$.

The larvae (second instar) of $A$. monuste and adults of the ant predator S. saevissima were placed in contact with cabbage leaf disks $(7.5 \mathrm{~cm})$ that were sprayed with insecticides or control on days $0,3,5,8,11,16,19,22,31,43$ and 60 . The leaves from the sprayed plants were collected randomly on these days and placed in a plastic pot $(250 \mathrm{~mL})$. Each plastic pot contained one cabbage leaf disk and ten individuals (A. monuste or S. saevissima). To feed the ants, honey and water in proportions of 1:1 and pure water were supplied in plastic containers $(1.5 \mathrm{~cm}$ diameter $\times 1.0 \mathrm{~cm}$ high) inside each pot. The bioassays were conducted in our laboratory; the conditions were $25 \pm 1{ }^{\circ} \mathrm{C}$, relative humidity of $75 \pm 5 \%$ and a 12:12 h photoperiod. We assessed insect mortality after $48 \mathrm{~h}$ of exposure.

\subsection{Statistical analyses}

The insect mortalities caused by insecticides were corrected in relation to the mortalities caused by the control using the formula of Abbott. ${ }^{24}$ The mortality data of $A$. monuste from the selection bioassay were assessed through an analysis of variance and Tukey's honestly significant difference (HSD) test $(P<0.05) .^{25}$

The mortality of pest and predator determined in the insecticide selection and physiological selectivity bioassays, respectively, were analyzed using Student's $t$-test $(P<0.05)$. We considered the insecticides that showed physiological selectivity to the predator to be those that caused higher mortality to the pest than to the predator. ${ }^{2,6}$ The mortalities from insecticides and insecticide + synergist combinations were analyzed using Student's $t$-test $(P<0.05) .^{25}$

The corrected mortalities of each insect as a function of time after each insecticide spraying were submitted to regression analysis $(P<0.05)$. The regression model used was the logistic dose-response curve (parameters $a, b, c$ and $d$ ) represented by the equation $Y=a+b\left[1+(X / c)^{d}\right]^{-1}$, where $Y=$ mortality (\%) and $X=$ time (days) after spraying. ${ }^{26}$ The residual period of control was defined as duration after spraying that the pesticide caused a pest mortality of $\geq 80 \%$. This mortality threshold was used because, in Brazil, an insecticide is considered efficient if it results in at least $80 \%$ mortality of the pest. ${ }^{22}$ For the predator, a period in which the mortality was greater than or equal to $80 \%$ was considered a period of high impact on the predator. However, a period in which the mortality was less than $30 \%$ was considered the period of low impact on the predator. According to the IOBC (International Organization for Biological Control), harmful activity to natural enemies can be categorized as high impact (mortality $\geq 80 \%$ ) or low impact (mortality $<30 \%) .{ }^{23}$ Correlation analyses $(P<0.05)$ were conducted between the characteristics of the insecticides (Table 1) and the residual period of control of the pest for each insecticide.

\section{RESULTS}

\subsection{Efficiency of insecticidal control of $A$. monuste}

We found significant differences in the mortality of $A$. monuste with respect to the insecticide used $\left(F_{9,50}=31.42, P<0.0001\right)$. The insecticides cartap, chlorfenapyr, deltamethrin, indoxacarb, malathion, methomyl and spinosad were the most toxic to A. monuste (100\% mortality), followed by chlorantraniliprole and cyantraniliprole, which caused larval mortality of $81.20 \%$ and $86.32 \%$, respectively. However, flubendiamide caused only $51.76 \%$ mortality, thus demonstrating a toxicity below the absolute threshold of $80 \%$ mortality required by Brazilian legislation (Fig. 1).

\subsection{Physiological selectivity of insecticides to the predator S. saevissima}

The exposure of predator S. saevissima to the insecticide treatments under investigation led to significantly different mortalities $\left(F_{8,45}=227.47, P<0.0001\right)$. Cartap, chlorfenapyr, deltamethrin, malathion and methomyl exhibited higher toxicity to $S$. saevissima, resulting in $100 \%$ mortality. In contrast, chlorantraniliprole, cyantraniliprole, indoxacarb and spinosad were less toxic, resulting in mortality ranging from nearly zero to $13.12 \%$ (Fig. 1).

The insecticides chlorantraniliprole $\left(t_{10}=44.91, P<0.001\right)$, cyantraniliprole $\left(t_{10}=7.71, P<0.001\right)$, indoxacarb $\left(t_{10}=264.20\right.$, $P<0.001)$ and spinosad $\left(t_{10}=30.98, P<0.001\right)$ caused greater 

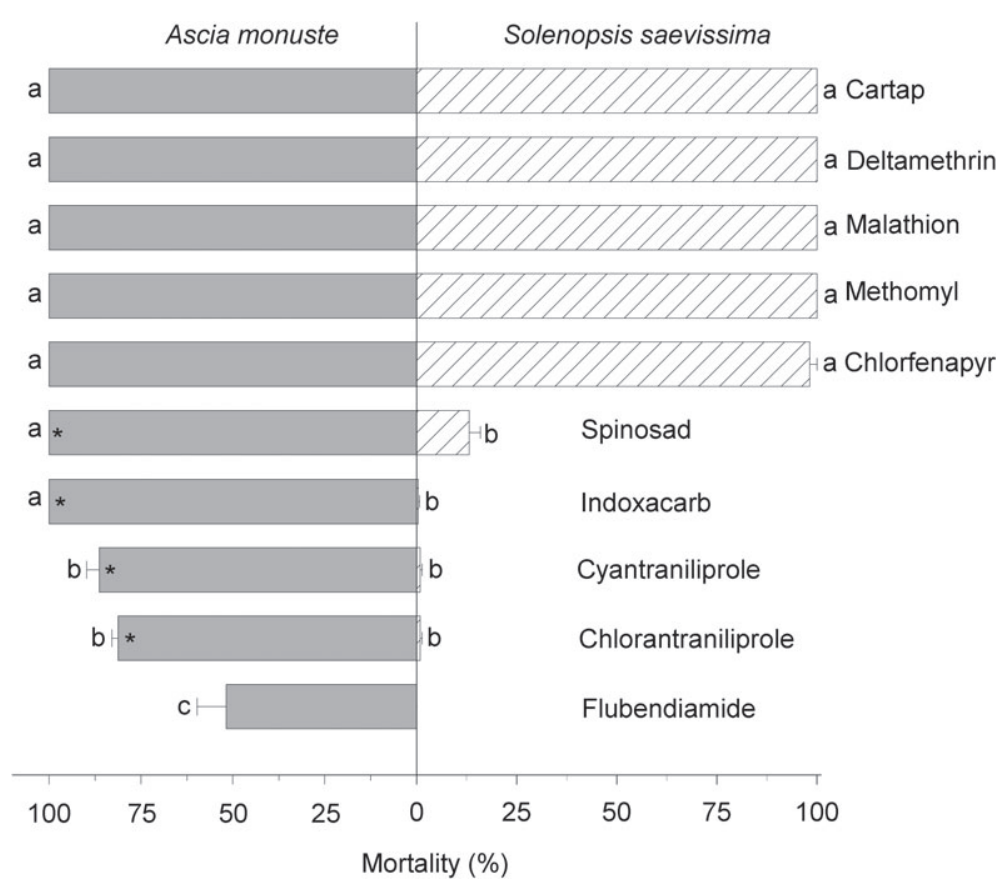

Figure 1. Mortality (mean \pm standard error) of Ascia monuste larvae and of Solenopsis saevissima adults exposed to the recommended field rate of insecticides. Histogram bars with the same lower-case letter do not differ significantly by Tukey's honestly significant difference test $(P<0.05)$. Histogram bars with an asterisk indicate that the mortality caused by the same insecticide is significantly higher for A. monuste than for S. saevissima by Student's $t$-test at $P<0.05$.

mortality to A. monuste than to the predator S. saevissima. Therefore, these insecticides showed physiological selectivity in favor of the predator. In contrast, cartap, chlorfenapyr, deltamethrin, malathion and methomyl showed no physiological selectivity because they caused similar mortalities to both species (Fig. 1).

The synergized insecticides had no antagonistic effect on the toxicity to the predator for all insecticides tested. No effect was verified for chlorantraniliprole and cyantraniliprole, but for indoxacarb and spinosad the addition of synergists led to synergism, increasing the mortalities. Piperonyl butoxide significantly increased the mortality of $S$. saevissima caused by indoxacarb $\left(t_{10}=264.20, P<0.001\right)$ and spinosad $\left(t_{10}=18.72, P<0.001\right)$. The synergist piperonyl butoxide led to the greatest increase in mortality when it was added to indoxacarb, from nearly zero to $100 \%$. Diethyl maleate significantly increased the mortality caused by spinosad $\left(t_{10}=12.53, P<0.001\right)$ from $13 \%$ to $85 \%$. Triphenyl phosphate significantly increased the mortality caused by indoxacarb $\left(t_{10}=3.25, P=0.009\right.$ ) from nearly zero to $30 \%$ (Fig. 2).

\subsection{Residual period of control of $A$. monuste and impact of insecticide on the predator S. saevissima as a function of time after spraying in greenhouse}

Regression models $(P<0.05)$ describing the mortalities of A. monuste and S. saevissima as functions of time after application of insecticides to cabbage plants were obtained (Figs 3 and 4). The mortalities caused by chlorfenapyr and cyantraniliprole to $A$. monuste did not vary over a 60 -day period. In contrast, the mortalities caused by cartap, chlorantraniliprole, deltamethrin, indoxacarb, malathion, methomyl and spinosad to A. monuste under the same conditions decreased over time. Although these insecticides all decreased the mortality over the time, different patterns of this mortality decrease can be observed when we consider the residual period of control of each insecticide (mortality caused $\geq 80 \%$ ).



Figure 2. Mortality (mean \pm standard error) of adults of Solenopsis saevissima exposed to selected insecticides with and without the synergists diethyl maleate, triphenyl phosphate, and piperonyl butoxide. Histogram bars with an asterisk are significantly different from treatments using only the insecticide (without a synergist) by Student's $t$-test at $P<0.05$.

After 3 days of spraying, malathion and methomyl showed the lowest residual period of control of $A$. monuste (i.e., after 3 days they caused mortality lower than $80 \%$ ). However, the other treatments continued to cause high mortalities to A. monuste (>80\%) at 3 days after spraying. Cartap and deltamethrin displayed a residual period of control of 16 days, followed by the insecticides chlorantraniliprole and indoxacarb (22 days) and spinosad (31 days). 


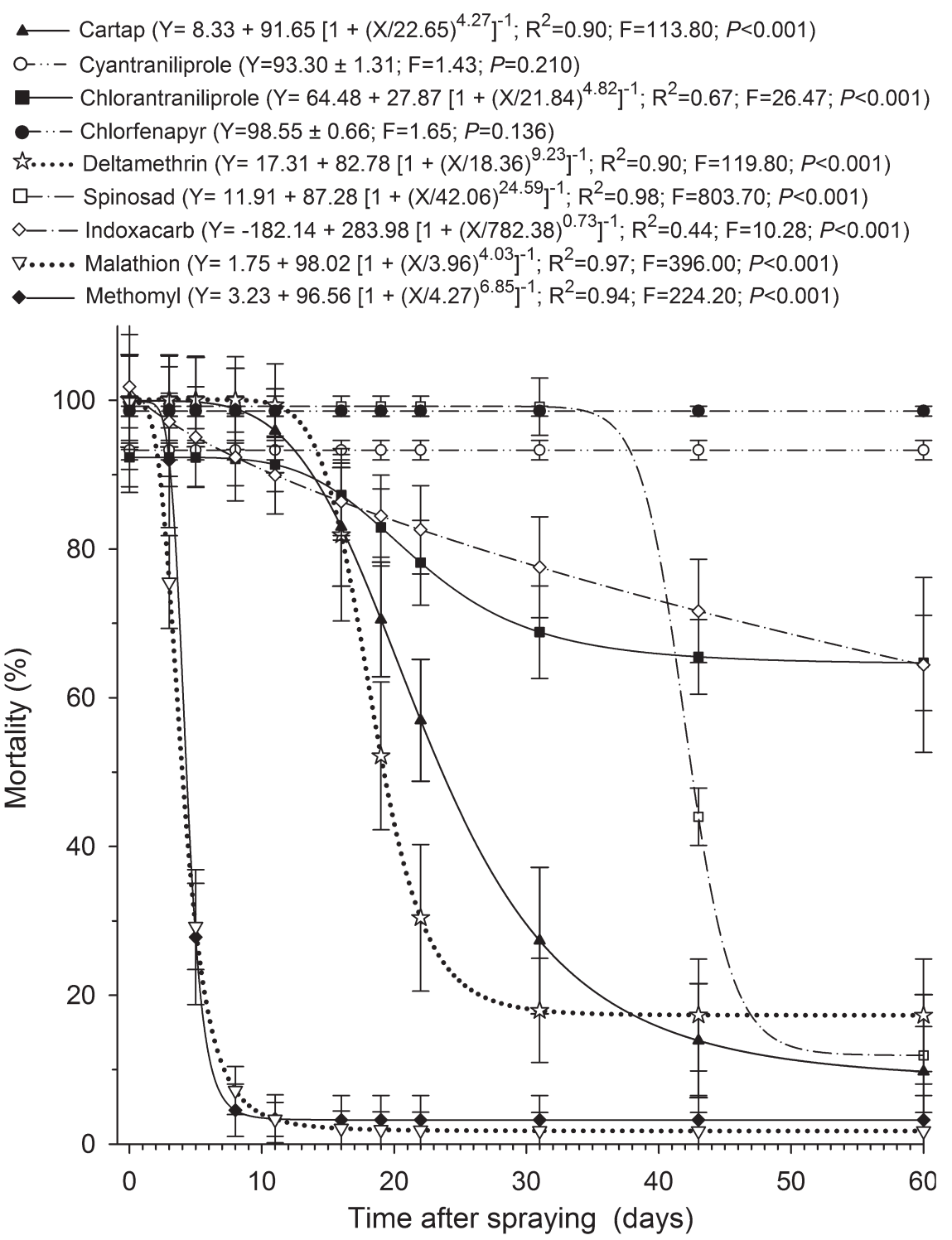

Figure 3. Mortality curves (mean \pm confidence interval) of larvae of Ascia monuste as a function of time after spraying nine insecticides.

Therefore, most of the treatments did not show efficient control of A. monuste (mortality $\geq 80 \%$ ) throughout the experimental period. The residual period of control of $A$. monuste was positively correlated with the half-lives of the insecticides on the leaves $(r=0.65$, $t=2.27, P=0.029$ ) (Fig. 3 and Table 1).

There was no loss of mortality caused by the insecticide malathion to the predator S. saevissima during a 60-day period (Fig. 4). However, under the same conditions, insecticide-induced mortality of S. saevissima decreased over time for cartap, chlorfenapyr, deltamethrin and methomyl. Methomyl greatly impacted the predator (mortality $\geq 80 \%$ ) only on the first day after spraying, and it had a lower impact (mortality $<30 \%$ ) 3 days after spraying. Deltamethrin was highly toxic to $S$. saevissima up to 3 days after spraying, but we observed a low impact starting at 5 days after spraying this same insecticide. Chlorfenapyr had a high impact on the predator for up to 11 days after spraying, whereas toxicity declined to $<20 \%, 31$ days after spraying. After malathion, cartap had the greatest impact on the predator for the longest period of time. For 22 days, it showed high toxicity to the predator, which slowly declined to zero in the 60th day after spraying (Fig. 4).

\section{DISCUSSION}

The insecticides cartap, chlorantraniliprole, chlorfenapyr, cyantraniliprole, deltamethrin, indoxacarb, malathion, methomyl and spinosad exhibited high toxicities to $A$. monuste, resulting in larval mortalities greater than the minimum efficacy threshold required by Brazilian legislation ( $80 \%$ mortality). This result indicates that these products may be used to control $A$. monuste. Despite the high toxicity exhibited, these products must be used in active principle rotation to control $A$. monuste and prevent this pest population from selecting for resistance to these insecticides. ${ }^{27}$ For example, chlorantraniliprole and cyantraniliprole (diamides) should not be applied consecutively in rotation because they have the same active principle that acts in the modulation of ryanodine receptors. ${ }^{28}$ Similarly, malathion (organophosphate) and methomyl (carbamate) act primarily to inhibit the enzyme esterase acetylcholinesterase (AChE) and thus should not be used subsequently in rotation. Thus rotating products with different active principles promotes an adequate pest management and can avoid problems such as a failure of pest control due to the emergence of insect resistance. ${ }^{27,29}$ 


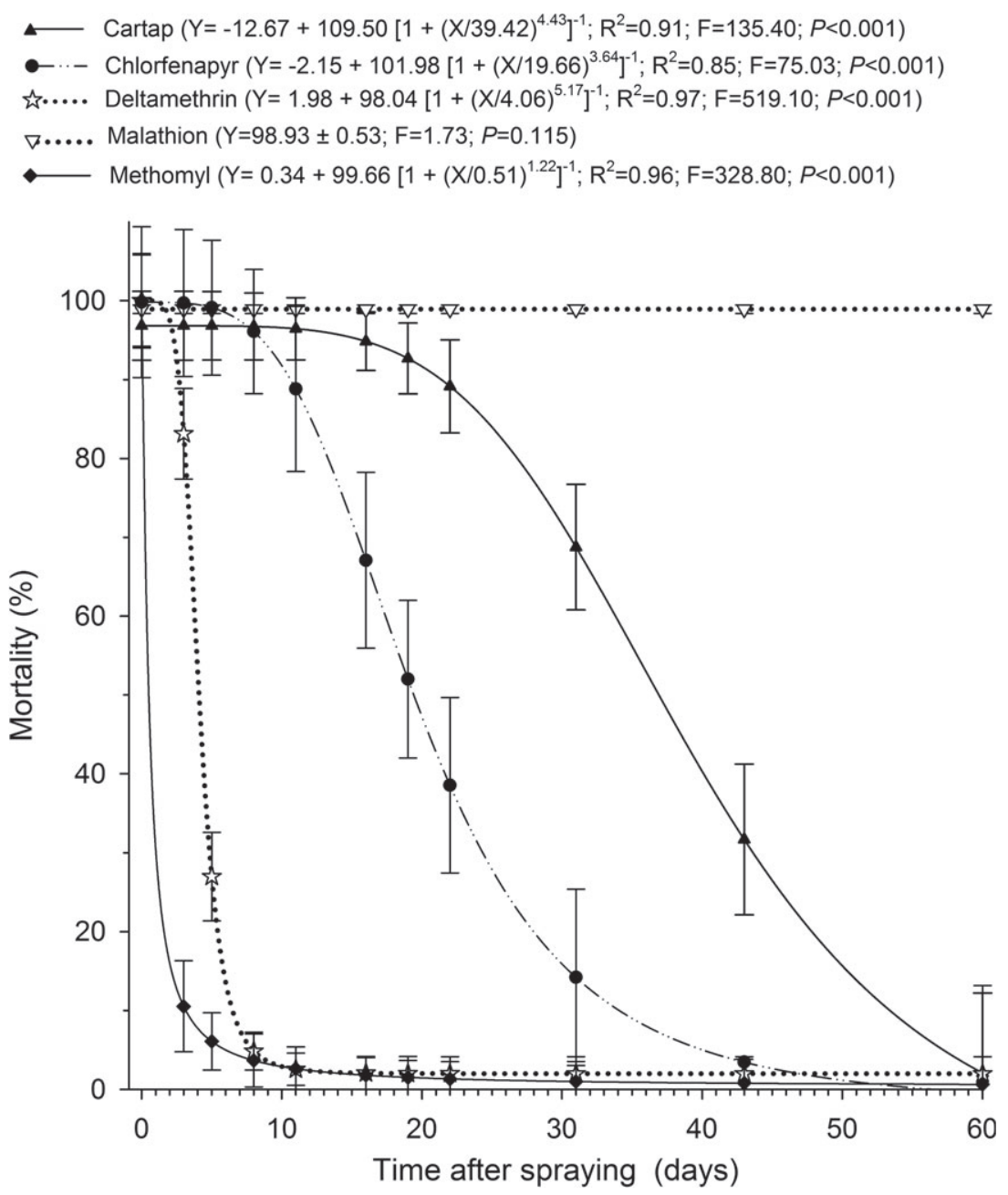

Figure 4. Mortality curves (mean \pm confidence interval) of adults of Solenopsis saevissima as a function of time after spraying the five insecticides that did not show physiological selectivity.

Although the insecticides cartap, chlorfenapyr, deltamethrin, malathion and methomyl were effective at controlling A. monuste, none showed physiological selectivity in favor of the predator. Therefore, the use of these insecticides must be based on the principles of ecological selectivity. The principles of ecological selectivity include adopting approaches in which the exposure of natural enemies to the insecticide is minimized. ${ }^{2}$ This can be achieved by applying the insecticide to a specific location on the plant where the pest attack occurs and/or at a time of low incidence of natural enemies (e.g., day or night). ${ }^{6}$ For instance, the soil is the foraging site for the ant S. saevissima; therefore, when controlling $A$. monuste, the insecticide should not be applied in soil, and the spraying must use the smallest possible volume of solution to prevent the insecticide from reaching the soil. ${ }^{20}$ Moreover, the insecticide should not be sprayed at night because the predatory activity of ants is higher in this period. ${ }^{19,30}$

The insecticides cyantraniliprole, chlorantraniliprole, spinosad and indoxacarb showed physiological selectivity to S. saevissima because they exhibited lower toxicity to the predator (mortality $\leq 13 \%)$. The use of insecticides with physiological selectivity to natural enemies is recommended in integrated pest management programs because, in addition to controlling the pest, these insecticides preserve the biological control agents. ${ }^{2,31}$ The selectivity of the insecticides chlorantraniliprole and cyantraniliprole has also been reported for other natural enemies. ${ }^{6,32}$ These insecticides, which belong to the group of diamides, are known for their affinity to ryanodine receptors of lepidopterans such as A. monuste and are thus considered safe products for non-target organisms. ${ }^{6,28}$ Likewise, a variety of beneficial insects have been observed to which the insecticide spinosad exhibits selectivity, most of which are predators. ${ }^{32,33}$ Indoxacarb is a pro-insecticide, which contributes it to being considered a safe and selective product. Its decarbomethoxylated metabolite is a voltage-dependent blocker of sodium channels. The selectivity of indoxacarb may be related to the low bioactivation of esterases and/or transferases, which may be observed in some parasitoids, bugs, chrysopids and coccinellids. , $^{6,34,35}$

The synergism obtained with piperonyl butoxide suggests the involvement of the enzyme cytochrome P450-dependent monooxygenase in the detoxification process of the insecticides indoxacarb and spinosad. The addition of the synergist piperonyl butoxide (an inhibitor of cytochrome P450-dependent monooxygenases) to these insecticides caused an increase in mortality of the predator, thus indicating the relevant role of this enzyme in the detoxification of xenobiotics in this species. The importance of this enzyme for the metabolization and bioactivation of insecticides has been reported for a variety of arthropod species, such 
as bugs, bees, caterpillars and parasitoids, and may be the case for ants. $6,14,36$

Our results also provide support for the idea that esterases and glutathione $S$-transferases are involved in the detoxification process of xenobiotics in the predator's body. The significant increase in predator mortality upon exposure to indoxacarb in combination with the synergist triphenyl phosphate (an esterase inhibitor) suggests that carboxylesterase is involved in this process, although this enzyme is also related to the bioactivation of indoxacarb through hydrolysis. ${ }^{6}$ This dual function of esterases in both processes has been reported, thus supporting the findings of this study. ${ }^{37,38}$ Similarly, inhibition of the enzyme glutathione $S$-transferases by diethyl maleate synergist promoted a synergistic effect when it was applied with spinosad, suggesting the involvement of this enzyme in the detoxification process of xenobiotics.

However, the synergists had little to no effect on the toxicity of insecticides chlorantraniliprole and cyantraniliprole because their addition resulted in neither synergism nor antagonism. Therefore, the enzymes cytochrome P450-dependent monooxygenases, esterases and glutathione $S$-transferases are not involved in the detoxification process of these products in S. saevissima, which indicates that the cause of selectivity of these insecticides is likely due to their affinity for Lepidoptera ryanodine receptors..$^{6,28}$

The residual effect of an insecticide is related to many factors, such as its degradation rate over time. ${ }^{39}$ This fact was confirmed in this study when we observed a positive correlation between the residual period of control of $A$. monuste and the half-life of products on the leaves. Moreover, the different residual periods of control of $A$. monuste among the insecticides have implications for integrated management programs of this pest. For malathion and methomyl, which showed the lowest residual period of control, a higher spraying frequency is recommended, in contrast to spinosad and, in particular, chlorfenapyr and cyantraniliprole, which had the highest residual periods of control. A spraying frequency between these extremes is recommended for cartap, chlorantraniliprole, deltamethrin and indoxacarb. It has been reported that high spray frequencies of pesticides are related to a higher incidence of pest resistance to pesticides, higher production costs and occupational health problems among farmers. $22,40,41$ Thus knowing the period of residual control for the products used in pest control is essential and can contribute to pest management in an economically, socially and environmentally correct way while avoiding unnecessary pesticide applications. ${ }^{42}$

Over the 60 days, not all of the insecticides had an impact on the predator. Methomyl and deltamethrin, despite not showing physiological selectivity, no longer impacted the predator after 10 days. In contrast, malathion had an impact throughout the 60-day period. The use of the insecticide malathion should therefore be avoided because it did not display physiological selectivity and greatly impacted the predator after spraying. Replacing malathion with insecticides that had lower impacts on the predator or with insecticides such as cyantraniliprole or chlorantraniliprole, which show more favorable environmental safety profiles, should be considered.

\section{CONCLUSIONS}

We evaluated the toxicity of the ten insecticides on $A$. monuste and its predator. The results support the use of novel insecticides chlorantraniliprole, cyantraniliprole, indoxacarb and spinosad. In addition to being efficient to the pest, these novel insecticides exhibited physiological selectivity to the predator. If cyantraniliprole is adopted in a management program, its spraying frequency must be lower than that of the other insecticides, which can lead to cost savings. In contrast, the results obtained for malathion, an older insecticide, support its replacement with other insecticides due its lower residual period of pest control and its greater impact on the predator.

\section{ACKNOWLEDGMENTS}

We wish to thank the National Council of Scientific and Technological Development (CNPq), the CAPES Foundation from the Brazilian Ministry of Education and the Minas Gerais State Foundation of Research Aid (FAPEMIG) for the financial support provided. We also wish to thank the manufacturing companies for donating their insecticide products.

\section{REFERENCES}

1 Matthews GA, Attitudes and behaviours regarding use of crop protection products: a survey of more than 8500 smallholders in 26 countries. Crop Prot 27:834-846 (2008).

2 Bacci L, Picanço MC, Rosado JF, Silva GA, Crespo ALB, Pereira EJG et al., Conservation of natural enemies in brassica crops: comparative selectivity of insecticides in the management of Brevicoryne brassicae (Hemiptera: Sternorrhyncha: Aphididae). Appl Entomol Zool 44:103-113 (2009).

3 Gontijo PC, Picanço MC, Pereira EJG, Martins JC, Chediak M and Guedes RNC, Spatial and temporal variation in the control failure likelihood of the tomato leaf miner, Tuta absoluta. Ann Appl Nematol 162:50-59 (2012).

4 Ripper WE, Greenslade RM and Harltey GS, Selective insecticides and biological control. J Econ Entomol 44:448-459 (1951).

5 Bacci L, Pereira EJG, Fernandes FL, Picanço MC, Crespo ALB and Campos MR, Seletividade fisiológica de inseticidas a vespas predadoras (Hymenoptera: Vespidae) de Leucoptera coffeella (Lepidoptera: Lyonetiidae). BioAssay 1:1-10 (2006).

6 Pereira RR, Picanço MC, Santana PA Jr, Moreira SS, Guedes RNC and Corrêa AS, Insecticide toxicity and walking response of three pirate bug predators on the tomato leaf miner Tuta absoluta. Agric Forest Entomol 16:217-325 (2014).

7 Wigglesworth VB, The distribution of esterase in nervous system and other tissues of the insect Rhodnius prolixus. Q J Microsc Sci 99:441-450 (1958).

8 Maibèche-Coisne M, Merlin C, Francois MC, Queguiner I, Porcheron P and Jacquin-Joly E, Putative odorant-degrading esterase CDNA from the moth Mamestra brassicae: cloning and expression patterns in male and female antennae. Chem Senses 29:381 - 390 (2004).

9 Vander Meer RK, Obin MS, Zawistowski S, Sheehan KB and Richmond $\mathrm{RC}$, A reevaluation of the role of cis-vaccenyl acetate, cis-vaccinol, and esterase- 6 in the regulation of mated female sexual attractiveness in Drosophila melanogaster. J Insect Physiol 32:681 - 686 (1986).

10 Kamita SG, Hinton AC, Wheelock CE, Wogulis MD, Wilson DK, Wolf NM et al., Juvenile hormone (JH) esterase: why are you so $\mathrm{JH}$ specific? Insect Biochem Mol Biol 33:1261 - 1273 (2003).

11 Terriere LC, Induction of detoxification enzymes in insects. Annu Rev Entomol 29:71-88 (1984).

12 Enayati AA, Ranson $\mathrm{H}$ and Hemingway J, Insect glutathione transferases and insecticide resistance. Insect Mol Biol Biochem 14:3-8 (2005).

13 Feyereisen R, Insect P450 enzymes. Annu Rev Entomol 44:507-533 (1999).

14 Kulkarni AP and Hodgson E, The metabolism of insecticides: the role of monooxygenase enzymes. Annu Rev Pharmacol Toxicol 24:19-42 (1984).

15 CABI, Crop Protection Compendium Pest Data Sheet. [Online]. Available: http://www.cabi.org/cpc/datasheet/41162 [1 January 2015].

16 Liu TX, Biology and life history of Ascia monuste monuste (Lepidoptera: Pieridae), a potential pest of cruciferous vegetables. Ann Entomol Soc Am 98:726-731 (2005). 
17 Schilick-Souza EC, Baldin ELL and Lourenção AL, Variation in the host preferences and responses of Ascia monuste orseis Godart (Lepidoptera: Pieridae) to cultivars of collard greens Brassica oleracea (L) var acephala. J Pest Sci 84:429-436 (2011).

18 Morais EGF, Picanço MC, Sena ME, Bacci L, Silva GA and Campos MR, Identificação das principais pragas de hortaliças no Brasil, in Manejo Integrado de Doenças e Pragas: Hortaliças, ed. by Zambolim L, Lopes CA, Picanço MC and Costa H. UFV, Viçosa, Brazil, pp. 199-232 (2007).

19 Ramos RS, Picanço MC, Santana PA Jr, Silva EM, Bacci L, Gonring AHR et al., Natural biological control of lepidopteran pests by ants. Sociobiology 59:1389-1399 (2012).

20 Way MJ and Khoo KC, Role of ants in pest management. Annu Rev Entomol 37:479-503 (1992).

21 MAPA, Ministério da Agricultura, Pecuária e Abastecimento. AGROFIT, Apresenta informações sobre produtos fitossanitários usados na agricultura. [Online]. Available: http://www.agricultura.gov.br/ agrofit [18 January 2015].

22 Silva GA, Picanço MC, Bacci L, Crespo ALB, Rosado JF and Guedes RNC, Control failure likelihood and spatial dependence of insecticide resistance in the tomato pinworm, Tuta absoluta. Pest Manage Sci 67:913-920 (2011).

23 Hassan SA, Bigler F, Bogenschütz $\mathrm{H}$, Boller E, Brun J, Calis JNM et al., Results of the fifth joint pesticide testing programme carried out by the IOBC/WPRS Working Group 'Pesticides and Beneficial Organisms'. Entomophaga 36:55-67 (1991).

24 Abbott WS, A method of computing the effectiveness of an insecticide. J Econ Entomol 18:265-266 (1925).

25 SAS Institute, SAS/STAT User's Manual version 9.4. SAS Institute, Cary, NC (2013).

26 Vasquez-Castro JA, Baptista GC, Gadanha CD Jr and Trevizan LRP, Insecticidal effect and residual action of fenitrothion and esfenvalerate on Sitophilus oryzae and Szeamais (Coleoptera: Curculionidae) in stored maize and wheat. ISRN Agron 2012:1 - 11 (2012).

27 Cloyd RA, Pesticide mixtures and rotations: are these viable resistance mitigating strategies? Pest Technol 4:14-18 (2010).

28 Lahm GP, Stevenson TM, Selby TP, Freudenberger JH, Cordova D, Flexner L et al., Rynaxypyr $r^{\mathrm{T}}$ : a new insecticidal anthranilic diamide that acts as a potent and selective ryanodine receptor activator. Bioorg Med Chem Lett 17:6274-6279 (2007).

29 Gong YJ, Wang ZH, Shi BC, Kang ZJ, Zhu L, Jin GH et al., Correlation between pesticide resistance and enzyme activity in the diamondback moth, Plutella xylostella. J Insect Sci 13:135 (2013).
30 Folgarait PJ, Ant biodiversity and its relationship to ecosystem functioning: a review. Biodivers Conserv 7:1221-1244 (1998).

31 Naranjo SE, Conservation and evaluation of natural enemies in IPM systems for Bemisia tabaci. Crop Prot 20:835-852 (2001).

32 Campos MR, Picanço MC, Martins JC, Tomaz AC and Guedes RNC, Insecticide selectivity and behavioral response of the earwig Doru luteipes. Crop Prot 30:1535-1540 (2011).

33 Williams T, Valle $J$ and Viñuela $E$, Is the naturally derived insecticide Spinosad ${ }^{\circledR}$ compatible with insect natural enemies? Biocontrol Sci Technol 13:459-475 (2003).

34 Roubos CR, Rodriguez-Saona C, Holdcraft R, Mason KS and Isaacs $\mathrm{R}$, Relative toxicity and residual activity of insecticides used in blueberry pest management: mortality of natural enemies. J Econ Entomol 107:277-285 (2014).

35 Zhao X, Ikeda T, Yeh JZ and Narahashi T, Voltage-dependent block of sodium channels in mammalian neurons by the oxadiazine insecticide indoxacarb and its metabolite DCJW. Neurotoxicology 24:83-96 (2003).

36 Siqueira HAA, Guedes RNC and Picanco MC, Cartap resistance and synergism in populations of Tuta absoluta (Lep., Gelechiidae). J Appl Entomol 124:233-238 (2000).

37 Nehare S, Moharil MP, Ghodki BS, Lande GK, Bisane KD, Thakare AS et al., Biochemical analysis and synergistic suppression of indoxacarb resistance in Plutella xylostella L. J Asia Pac Entomol 13:91 -95 (2010).

38 Afzal MBS and Sarfraz AS, Genetic analysis, realized heritability and synergistic suppression of indoxacarb resistance in Phenacoccus solenopsis Tinsley (Homoptera: Pseudococcidae). Crop Prot 84:62-68 (2016).

39 Lu MX, Jiang WW, Jian Q, Shen Y, Liu XJ and Yu XY, Persistence and dissipation of chlorpyrifos in Brassica chinensis, lettuce, celery, asparagus lettuce, eggplant, and pepper in a greenhouse. PLOSONE. https://doi.org/10.1371/journal.pone.0100556 (2014).

40 Kamijima M, Hibi H, Gotoh M, Taki K, Saito I, Wang H et al., A survey of semen indices in insecticide sprayers. J Occup Health 46:109-118 (2004).

41 Ntow WJ, Gijzen HJ, Kelderman P and Drechsel P, Farmer perceptions and pesticide use practices in vegetable production in Ghana. Pest Manage Sci 62:356-365 (2006).

42 Pimentel D, McLauhlin L, Zepp A, Lakitan B, Kraus T, Kleinman P et al., Environmental and economic effects of reducing pesticide use in agriculture. Agric Ecosyst Environ 46:273-288 (1993). 